This is the post print version of the article, which has been published in Philosophical explorations. 2018, 21 (1), 90-107. http://dx.doi.org/10.1080/13869795.2017.1421693 .

\section{Kant and Hegel on Purposive Action}

Arto Laitinen

Department of Philosophy

University of Tampere

Arto.Laitinen@uta.fi

\section{Erasmus Mayr}

Department of Philosophy

Friedrich-Alexander-Universität Erlangen-Nürnberg

erasmus.mayr@fau.de

\section{Constantine Sandis}

Department of Philosophy

University of Hertfordshire

c.sandis@herts.ac.uk

\title{
Abstract
}

This essay discusses Kant's and Hegel's philosophies of action and the place of action within the general structure of their practical philosophy. We begin by briefly noting a few things that both unite and distinguish the two philosophers. In the sections that follow we consider these and their corollaries in more detail. In so doing, we map their differences against those suggested by more standard readings that treat their accounts of action as less central to their practical philosophy. Section II discusses some central Kantian concepts (Freedom, Willkür, Wille, and Moral Law). In Section III we take a closer look at the distinction between internal and external action, as found in Kant's philosophy of morality and legality. In Section IV, we turn to Hegel and his distinctions between abstract right (legality), morality, and ethical life, as well as the location of his account of action within his overall theory of morality. We discuss the distinction between Handlung and Tat, and non-imputable consequences. The overall aim of our essay is to shed light on some puzzles in Kant and Hegel's conceptions, and to examine where their exact disputes lie without taking a stand on which philosophy is ultimately the most satisfactory.

Keywords: Kant, Hegel, Action, Will, Freedom, Ethics, Handlung, Tat, Willkür, Wille, Moral Law.

\section{Introduction}

Our discussion builds upon three general points of similarity and difference between Kant and Hegel. ${ }^{1}$ First, they are both philosophers of freedom, autonomy, reason, and will. So they share much in their opposition of physicalist "naturalism" in all its different stripes. Accordingly, they both maintain that human agents (a) have Willkür (a faculty to do or refrain from doing as one pleases) and are free agents (not slaves of the passions or necessitating inclinations) and (b) are able to assess their reasons or grounds for action and decide as Reason dictates. Both philosophers maintain, moreover, that free Will is comprised of the above, pace more existentialist versions of freedom. As we shall see, however, they cash out reason and will in ways that make a significant difference to their accounts of action and ethics.

Second, Kant makes sharp dichotomies, whereas the Hegel thinks that dichotomies must be overcome in a unity which preserves, or 'sublates' the best of both sides, claiming that they are 'moments' in the whole (SL, §184-187). While Hegel inherits Kant's distinctions (of the determination of will by empirical 
desires vs determination by reason and autonomous self-determination vs heteronomous external determination) he proceeds as a 'unifier' who sees the apparent opposites as ultimately connected in ways that aim at 'sublating' the Kantian dichotomies in a richer, differentiated kind of unity.

With regard to agency, Kant stresses the distinction between autonomy and heteronomy: between oneself and various kinds of 'other'. Self-determination or autonomy is thus essential to freedom, with determination by various kind of 'other' amounting to heteronomy. In stark opposition, Hegel maintains that one can be oneself despite being affected by the 'other' - one can be oneself in and through the other. The 'orthonomy' (to use Philip Pettit's term, which Hegel did not use) will differ from purified autonomy. This affects their respective approaches to an agent's relation to four 'others': (a) empirical reality ('outer' nature); (b) their empirical inclinations ('nature within');(c) other agents; (d) prevailing social reality.

a) Hegel claims that one is what one does - one becomes oneself by shaping external reality so that one finds oneself there. By contrast, Kant seems to regard the results of one's actions in the external world as inessential both to the action's moral worth and to the core activity of the agent's will. At the beginning of the Groundwork he famously insists that the moral worth of a good will does not lie in "what it effects or accomplishes" and that the agent might have a good will even "if with its greatest efforts it should yet achieve nothing", ${ }^{2}$ which suggests that the core activity of the will would be unaffected by this failure. Thus, the crucial thing for Hegel is that the external nature and one's activity are related in the right way, whereas only the latter side of the dichotomy matters for Kant.

Kant's moral philosophy gives pride of place to the internal factors which move the agent to action (whence the crucial importance of subjective maxims' and their universalizability). Hegel, by contrast, begins with changes in the external world and only then asks which of them are consequences of this agent's deeds, which of them were foreseeable and so imputable to the agent, and which are the intended results. The direction of analysis for Hegel is equally that of "appropriating", "identifying with" or "owning" external events, as it is that of "expressing", "externalizing" one's purposes or intentions in the external world.

b) Kant draws a further dichotomy between one's empirical desires, sensations, and feelings and determination by reason: the former are not trustworthy guides to action which is in accordance with' moral duty. Even when they happen to lead to benevolent motivations, action which stemsfrom them lacks moral worth. Pure practical reason ought to be one's guide; one should not be a slave to passions. Hegel follows Aristotle in thinking that one's emotional and conative lives can accord with reason and they can be trusted as long as they are of the right kind, thanks to habituation and Bildung: they are equally aspects of oneself as one's critical faculties. Sentiments and passions need not be put aside as heteronomy, but can be an important guide to orthonomy.

c) The main foundation of morality, for Kant, lies in the individual agent's autonomy, which could, in principle, be discovered and followed by one agent in isolation. ${ }^{3}$ This allows for the possibility of a morally saintly Robinson, unlike Hegel's basic structure of 'being oneself in and through the other'., in which Self-consciousness and norm-guided agency are only possible insofar as they are recognized by others.

d) For Kant, authorities, conventions, and traditions represent heteronomy. One must take critical distance, and judge by oneself what is to be done. Hegel joins him here in thinking that pre-modern communal ethical life which didn't recognize the autonomy and right of subjectivity is to be criticized. 
However, Hegel thinks of such reliance on one's own judgement as merely one aspect, viz. that of Moralität, to be united with communal ethical life (Sittlichkeit), whose norms are rational. In such modern Sittlichkeit, authorities, conventions and customs need not be put aside as heteronomous, but can be endorsed in the name of 'orthonomy'.

Third, determination according to a universal law and determination by one's true self must, for Kant, be equivalent. By contrast, Hegel sees this contraposition between one's true (rational) self and both other parts of one's psychology and features of the natural and social world as much too 'black and white' a view, modifying it with the aforementioned structure of 'being oneself in another', thereby allowing for a differentiation between degrees of dependence. One's freedom, thus also comes in degrees, depending on the detailed features of the external situations, inner inclinations, the dependences on others and social role in which one finds oneself. So, whereas Kant holds that Reason, Will or the Moral Law are not 'external' to us (but that by obeying the law we obey ourselves), Hegel argues that the same goes for the other apparent others (external nature, inner nature, other agents, and society). They are not absolutely alien or other, but to varying degrees one may find oneself in them. In good cases, one may succeed in being one's true self by living in accordance with them.

\section{Kant on Rational Agency: Faculty of Desire, Willkür and Wille}

There is no single place in Kant's published writings at which he offers a systematic treatment, much less a definition, of agency. Nevertheless, there are several places where he deals in some detail with the capacities involved in agency, as well as with the 'mechanics' of certain kinds of motivation (especially moral motivation). In particular, at the beginning of the Introduction to The Metaphysics of Morals, Kant is at pains to distinguish three crucial faculties: The faculty of desire ("Begehrungsvermögen"), the faculty of choice ("Willkür"), and the will itself ("Wille", which Kant identifies with practical reason). Both the faculty of choice and the will are construed as specific forms of the more general form of the faculty of desire. This has two important consequences: it entails that Kant does not fully break with the traditional scholastic view of taking the will to be a rational form of desire ${ }^{4}$ and, further, has repercussions for how Kant conceives of desire itself.

The faculty of desire ('Begehren') is "the faculty to be, by means of one's representation, the cause of the objects of these representation". ${ }^{5}$ This is not restricted to human beings, but shared by animals, too; or at least those that have representations of objects that they are 'drawn towards' and are motivated to act by these representations. Agents with a faculty of desire thus go beyond merely 'inert' things in nature that are pushed and pulled solely according to external forces.

It is crucial that Kant's definition of the capacity of desire is only in terms of the causal efficaciousness of the representations in question, remaining conspicuously silent about the grounds of desire. In particular, it is no part of Kant's conception of desire that it is preceded or caused by a prior pleasure $^{6}$, an expectation of pleasure in the object of the desire, or by some mechanical attraction by this object (this is strikingly different to, say, Hobbes' definition of desire). Nor is desire in Kant's terminology something that we necessarily undergo passively. This is only true of the the inclinations and impulses of sensibility ('sensible desires'), which are not 'self-produced' (i.e. not produced by a judgement of reason). There are, however, inclinations which are 'self-produced', namely those which are the "effect[s] of [a] pure interest of reason, and we would call it a sense-free inclination". ${ }^{7}$ 
Kant's exclusion of the grounds for the desire from the definition of the faculty of desire radically distinguishes his conception of desire from that of the empiricist psychological terminology current in his day. The underlying motivation of this move is easy to understand: if we included a prior pleasure as the desire's ground we would de facto rule out the possibility of actions motivated solely by the recognition of duty from the outset and, pari passu, that there could be anything like the 'will' in Kant's sense. Excluding this possibility would strike at the very heart of Kant's theory of moral action. ${ }^{8}$ Including a judgement of reason's being the determining ground of desire would, by contrast, implausibly undercut the very possibility of wrongful, immoral, action.

Interestingly, Kant's neutrality on the potential grounds of desire allows him to concur with Hume on a question on which they are often held to be opponents, viz. that of whether a desire must be included among the factors that precede action. In fact, Kant seems to agree with Hume in thinking that among the proximate antecedents of action there must be some state which is not purely cognitive. Otherwise, it would be difficult to understand why Kant, at least in the Groundwork, considers the feeling of respect to be the subjective determinant of one's choice and action in moral actions (GMM AA 4: 401). This feeling appears to be needed in order for us 'to get going' (though it is not itself the result of some other feeling but a consequence of moral judgement). So, while Kant crucially disagrees with Hume about the original springs of motivation and desire - about the 'input' required for motivation - , they agree on the question of whether desire is needed for action.

Both the faculty of choice and the will are species of the genus faculty of desire:

The faculty of desire in accordance with concepts, insofar as the ground determining it to action lies within itself and not in its object, is called a faculty to do or refrain from doing as one pleases. Insofar as it is joined with one's consciousness of the ability to bring about its object by one's action it is called choice [Willkür]" (MS AA 6: 213).

The faculty of choice thus conjoins three elements. First, a faculty of desire in accordance with concepts. Second, the absence of an external determining ground (negatively) and, in its place (positively) the determining ground being found in the faculty of desire itself. Third, the consciousness of the ability to bring about the object in question. It is important to note, though, that the second of these features does not mean that the faculty of choice cannot be determined by sensual stimuli. Indeed, soon afterwards Kant proceeds to explicitly introduce the notion of 'animal choice' (arbitrium brutum), "which can be determined only by inclination" (6: 213). This suggests that the faculty of choice as such does not yet include the possibility of free choice and, as a matter of fact, the original German formulation ("nach Belieben zu thun oder zu lassen") lacks this implication. This raises the question of what distinguishes the faculty of choice (as distinguished from the free choice) from that of desiring in general. One key difference is that choice, for Kant, includes the representation of oneself as the cause of the envisaged effect, which was lacking in desire in general. This makes it plausible to identify the capacity for choice with the capacity of (conscious) intention, since when one intends to do $X$, one doesn't merely want $X$ to happen (and represent the occurrence of $X$ to oneself), but wants $X$ to happen as a result (or part of) what one does, and, as a result of having the intention to do it (thereby representing oneself as doing, or bringing about $X$ as a result of this intention). ${ }^{9}$ On the one hand, the connection between intentions and representing oneself as the cause of the envisaged effect explains why the former require at least an implicit belief that one can do what one intends to. On the other hand, for Kant it also explains why the capacity for choice brings with it a commitment to means-end-rationality. As he famously claims in the Groundwork the following sentence is analytic:

Whoever wills the end also wills (insofar as reason has decisive influence on his actions) the indispensably necessary means to it that are within his power (GMM AA 4: 417). 
The evident reason for this is that in willing an object as my effect, I already represent myself as the cause of this effect, which includes using the indispensable means by which my causality can bring about the latter. While Kant does not yet use in the Groundwork the terminology of the Metaphysics of Morals, it is highly plausible to read this passage as being concerned the kind of 'willing' that is constitutive of what he later comes to call the exercise of the faculty of choice.

Later on, Kant adds another crucial characterisation to the faculty of choice, in describing it as the faculty from which maxims are derived (GMM AA 6: 226). We leave it open here both whether this is meant to only apply to human choice and whether this is an extra characterisation or one which is already included in Kant's original definition of the faculty of choice. A maxim is a "subjective principle of willing, a principle which the subject himself makes his rule (how he wills to act)" (MM AA 4:225) and Kant famously holds that every intentional action is based on such a subjective principle (on whose universalizability or nonuniversalizability the test of the Categorical Imperative turns). This may seem surprising at first, since we regard many intentions as being completely 'one-time affairs' which lack the generality required for principles. So why should it be the case that in intentionally doing something, or even in deciding to do something, we necessarily 'make something a rule for ourselves'? As some philosophers have pointed out, it is not fully implausible to understand any intention as involving a kind of generality, since whenever I intend to do something, my intention must cover at least a certain "range of different possible cases". ${ }^{10}$ If, say, I decide to go to the opera tonight, I must commit myself to this course of action for at least a certain range of different scenarios, and to this extent, I commit myself, in virtue of forming the intention, to a certain 'principle', however limited its scope. If this is so, we can at least begin to see why the faculty of choice, understood as a faculty for forming intentions, is also the faculty of maxim-formation

Human choice, for Kant, is not determined by sensuous impulses. It can "indeed be affected but not determined by impulses" which crucially distinguishes it from animal choices, and makes it a "free choice" in the negative sense at least (AA 6: 213). This negative freedom is essentially connected to the fact that human choices are capable of being determined by pure reason, and the activity of the will consists in nothing other than in this determination: "The faculty of desire whose inner determining ground, hence even what pleases it, lies within the subject's reason is called the will." (loc. cit.) What does it mean that 'the inner determining ground [...] lies within the subject's reason'? The condition is best understood as saying that desire is determined by the relevant judgments issued by reason i.e. that agents act or desire on the basis of such judgements. Positive freedom of human choice lies in the capacity of being determined by the subject's reason, by her own recognition of what is good or morally required. And this, for Kant, famously requires that one is governed by one's recognition that one's maxim has a certain formal feature, passing the test of universalizability:

But this is not possible except by the subjection of the maxim of every action to the condition of its qualifying as universal law. For as pure reason applied to choice irrespective of its objects, it does not have within it the matter of the law; so as a faculty of principles [...] there is nothing it can make the supreme law and determining ground of choice except the form, the fitness of maxims of choice to be universal law (MM 6: 214).

It's noteworthy that for Kant the will includes by definition actual determination of one's intentions and actions by reason ("The will is ... the faculty of desire considered ... in relation to the ground determining choice to action", MM AA 6: 213). Free choice does not, for it only requires that the choice can be determined by pure reason.

In beings who, like us, possess reason but are at the same time subject to sensuous impulses, reason is indeed not automatically operative. Hence our ability to decide 'in favour of' following our sensuous 
impulses as against acting as it is morally required. As a result of this, the moral law, for us, comes in the shape of an 'imperative' (GMM AA 4: 412). This is different for a 'divine' or 'holy' will which would lack any other grounds for action other than those provided by reason. Even the choices made by the 'holy' will, however, count as free for Kant, since freedom of choice asymmetrically only requires the possibility of being determined by reason and not that of being determined by something else. The underlying ground for this asymmetry is that Kant does not consider the possibility of choosing in accordance with the dictates of reason and the possibility of choosing against them on a par: "Only freedom in relation to the internal lawgiving of reason is really an ability; the possibility of deviating from it is an inability." (MM AA 6: 227). Therefore, even though we can only make immoral choices because we have the capacity of free choice, "freedom of choice ... cannot be defined as the ability to make a choice for or against the law (libertas indifferentiae)" (MM AA 6: 226).

For Kant, determination by Reason is true self-determination. There are two noteworthy corollaries to this. First, since Reason is not something specific to me (or another individual agent), what excludes determination by external features (heteronomy) is determination by something which I share with others. Second, what motivates me when I act truly autonomously is the insight into the 'lawlikeness' of the principles that motivate me viz. that I realize that I could will these principles to be universal laws. Both consequences will sound odd to philosophers with more existentialist leanings, preferring to conceive of the true individual self precisely in opposition to general, seemingly impersonal laws. Kant offers a number of different considerations in support of his view. One line of thought is an 'argument from elimination', which resembles Rousseau's republicanism. Rousseau (1762) held that the only way to prevent citizens from being subordinate to other individuals' contingent wills was to make everyone subject to public, general laws given by all citizens together (as lawgivers). ${ }^{11}$ Being subject to such general laws was not being subject to anyone in particular, and if the law expressed everyone's will, then being subject to the law (albeit the law is the same for all concerned) was being subject to no-one but oneself. Kant similarly thinks that being subject to a self-determined universal law (albeit the same law for everyone) is being subject to no-one but oneself. That is true autonomy (in the strict sense of the word: 'self-lawgiving'), and the only way our actions can be determined by our true selves.

By contrast, being subject to one's natural passions, to others' contingent wills, to tradition, to the authority of prevailing society is for Kant to be heteronomous. Even a Sartrean 'radical chooser' would not achieve full autonomy for Kant (though he doesn't explicitly consider such a figure). While he is not determined to act by his natural passions but can arbitrarily choose to act on them or resist them, thereby exercising Willkür (which crucially distinguishes him from animals which are determined by inclinations and unable to choose), he still fails to give himself laws and act on them, which would be required for autonomy. That even a Sartrean 'radical chooser' would count as non-autonomous may seem counterintuitive, since such a figure is not a slave to passions but is said to be capable of resisting any temptation. Yet, for Kant, even the Sartrean radical chooser will choose randomly, and that is not true self-determination. Autonomy is thus not purely a negative notion for Kant (which would merely presuppose absence of external determination), but also a positive one. It is the latter feature which sets autonomy apart from random choice.

There is also another way, one even less congenial to many modern readers, in which Kant supports the need for universal laws for true autonomy, which rests on the connection between causality and universal laws. Self-determination, we might think, is a causal determination of one's actions by oneself. But due to Kant's adherence to a nomological view of causation, causation requires laws. In selfdetermination, these will not be natural laws, since determination according to such laws is not self- 
determination but determination by other causal factors. They must consequently be self-given laws, leaving the moral law as the only possible candidate. ${ }^{12}$

\section{Internal vs. external aspects of action in Kant and the 'original choice'}

Prima facie, Kant operates with a twofold distinction between aspects of actions in legal and moral contexts. First, the legal context concerns external actions, the moral context their subjective principles (or "maxims"). Second, due to his transcendental idealism, Kant maintains that we can distinguish between actions or, more properly, choices as noumena and actions as phenomena.

In The Metaphysics of Morals, Kant distinguishes between two types of 'laws of freedom' (laws which gives reasons to the faculty of choice without automatically determining the latter):

[T] hese laws of freedom are called moral laws. As directed merely to external actions (bloße äußere Handlungen) and their conformity to law they are called juridical laws; but if they require that they (the laws) themselves be the determining grounds of actions, they are ethical laws (MM 6: 214).

At first, this passage only seems to stress the well-known distinction between juridical laws, which do not demand that the agent complies with them for a particular reason, as long as he acts in accordance with them, and moral/ethical laws which (in addition) require that the agent acts for the right reasons. This distinction, which Kant himself did much to entrench in non-consequentialist ethics, has great intuitive appeal. While I can comply, say, with the criminal law forbidding murder even when I refrain from murdering only because I am afraid of being caught (and not out of respect for the criminal law or for my fellow beings), the motivation for my actions plays an obvious role for whether I have managed to comply with a moral law or not (and for the moral evaluation of my action). Kant explicates this in terms of a distinction between 'external action' and the agent's maxim, or 'how he wills'. This is stressed even more clearly when it comes to determining the so-called 'principle' of the (legal) right:

The concept of right [...] has to do, first, only with the external and indeed practical relation of one person and another, insofar as their actions, as deeds, can have (direct or indirect) influence on each other [...] Any action is right if it can coexist with everyone's freedom in accordance with a universal law, or if on its maxim the freedom of choice of each can coexist with everyone's freedom in accordance with a universal law [...] It also follows from this that it cannot be required that this principle of all maxims be itself in turn my maxim; for anyone can be free so long as I do not impair his freedom by my external action, even though I am quite indifferent to his freedom and would like in my heart to infringe upon it (MM 6: $230 \mathrm{f}$.).

The last sentence suggests that we can distinguish a notion of 'external action' (the subject of legal regulations) from a notion of 'inner action' or choice 'in my heart' (with which morality proper is concerned). Some of Kant's later remarks on how to demarcate between law and ethics support such a reading:

Ethics does not give laws for actions (ius does that), but only for maxims of actions (MM 6: 388). 
Yet it would be misleading to think of two different and separated entities - i.e. external actions and choice - which would be the different 'subject-matters' of law and ethics. Choices issue in external actions, and laws in general (both juridical and properly moral ones) are addressed to the agent's faculty of choice. They are efficient in guiding the agent only because she can cognize them and decide about what to do in the light of this cognition. This is the feature that distinguishes moral and juridical laws from natural ones, which determine the behaviour of objects regardless of whether these objects are aware of them. The content of juridical laws simply doesn't include motives or maxims. As Kant puts it:

[W] hen freedom in the external or internal use of choice is considered, its laws, as pure practical laws of reason for free choice generally, must also be internal determining grounds of choice, although they should not always be considered in this respect. (MM AA 6: 214 or 220) ${ }^{13}$

It would also be misleading to align the distinction between external action and choice with the distinction between phenomena and noumena (or things-as-they-appear and things-in-themselves). Kant famously holds that we are only acquainted with and can cognize 'things-as-they-appear-to-us', and that only in this respect things are located in a spatio-temporal framework, though we must also assume there are things-inthemselves, which do appear to us in this way. As Kant insists in the Critique of Pure Reason, this applies not just to 'outer things' but to our mind itself. When we experience a sequel of sensual impressions, even the temporally ordered sequence of purely 'mental' occurrences is only a matter of how our own mind appears to us, or of our own 'conception' of ourselves (CpR B $53 \mathrm{f}$.). The distinction thus also applies to our choices and actions. While it is tempting to think that external actions are just the manifestations of inner choices (and thus a matter of appearance), in rendering these actions the phenomena corresponding to the noumenal choices Kant makes it clear that we can draw the distinction with regard to choices themselves. For example, in MM 6: 226, he explicitly speaks of "choice as a phenomenon" about which we can gather insights from experience. This seems right, for not only can we make choices, we can also experience ourselves as making (and having made) them. Our experiences of the latter sort involve 'appearances of decisions'. Choice, considered as a noumenon, manifests itself in a phenomenal choice, which depends on how the noumenal choice affects our inner sense.

This distinction between choice as a noumenon and as a phenomenon is already presupposed for Kant's transcendental views from the Groundwork onwards. Kant's discussion in the Groundwork suggests that we deliberate about the morally right course of action and make choices about what to do in the actual action-situation, and that, roughly, a choice corresponds to each action. ${ }^{14}$ Yet, strictly speaking, this cannot be true on Kant's transcendental idealism, for time itself is only the form of the inner sense and does not apply to noumena. The choices we make, considered as things-in-themselves, cannot be temporally ordered in the same way the phenomenal choices and the actions in which they manifest themselves are!

It is only in the Religionsschrift, though, that Kant explicitly draws this radical conclusion, introducing the idea of a radical choice, by which we acquire a disposition to good or evil. The point of departure for Kant's thought here is that there must be a ground for morally good or evil choices, a "subjective ground for the use of his freedom" (Rel AA 6: 21). This ground, a propensity to good or evil, cannot be a natural inclination or propensity, but must be something which we freely choose ourselves as a maxim, since otherwise it could not make us morally good or evil. For we are not responsible for inborn inclinations or propensities, but only for those propensities of which we can ourselves be considered the 'authors', in 
virtue of having adopted a corresponding maxim. Still, the propensity to good or evil is not something 'acquired', but 'natural or inborn':

To have a good or an evil disposition as an inborn natural constitution does not here mean that it has not been acquired by the man who harbors it, that he is not author of it, but rather that it has not been acquired in time [...] Yet this disposition itself must have been adopted by free choice, for otherwise it could not itself be imputed. But the subjective ground or cause of this adoption cannot be further known [...] since otherwise still another maxim would have to be adduced in which this disposition must have been incorporated (Religion AA 6:21, emphasis added).

What would this free choice be, by which we have adopted a good or evil disposition? Setting aside the contested case of diabolical agents who choose bad actions because they are bad, the choice concerns the question of what to do when morality and self-interest conflict. We can either adopt the (general) maxim of subordinating our self-interest to the moral law (which would give us a good disposition) or vice versa. In either case, we may distinguish this first choice or adoption of maxim from the more particular choices, performed on its basis.

[N]othing is morally evil [...] but that which is our own act. On the other hand, by the concept of a propensity, we understand a subjective determining ground of choice which precedes all acts and which, therefore, is itself not an act. Hence in the concept of a simple propensity to evil there would be a contradiction, where it not possible to take the word 'act' in two meanings, both of which are reconcilable with the concept of freedom. The term 'act' can apply in general to that exercise of freedom whereby the supreme maxim (in harmony with the law or contrary to it) is adopted by choice, but also the exercise of freedom by which the actions themselves [...] are performed in accordance with that maxim. The propensity to evil, then is an act in the first sense ..., and at the same time the formal ground for all unlawful conduct in the second sense, which latter, considered materially, violates the law and is termed vice [...]; and the first offence remains, even though the second [...] may be repeatedly avoided. The former is intelligible action, cognizable by means of pure reason alone, apart from every sensible condition; the latter is sensible action, empirical, given in time (Religion AA 6: 31).

We must, then, distinguish between the choices which we make 'in time', before each action, and the original choice which has formed our character by giving us the good or evil disposition, manifested in particular choices of the first kind. The former is empirical, the latter noumenal. While this is arguably a straightforward consequence of Kant's theoretical philosophy, it remains a major departure both from our common-sense view of choices (on which we can decide freely in each single case) and from the picture suggested by Kant's earlier writings, which was much closer to this common-sense view.

\section{Hegel on Rational Agency: Oneself in Another}


Kant's view of Wilkür and Wille is "sublated" in Hegel's system. As already mentioned § 1, Hegel agrees with Kant that (a) Human agents have Willkür, a faculty to do or refrain from doing as one pleases. For Hegel, the structure of such a will includes three aspects (PR, §5-7). The first is indeed, the capacity to say "no" to any inclination or temptation, or any content whatsoever ("universal" negation, which alone would lead to emptiness) (PR§5). Other aspects of the will include the capacity to say 'yes' to something (affirmation of something 'particular'; thus negation of universal emptiness, i.e. negation of negation) (PR§6); and thirdly, the unity ("oneness", individuality) of these two powers. This includes the capacity to identify with the results of one's actions in the external reality (PRß7). ${ }^{15}$

Hegel also follows Kant in thinking that (b) human agents are able to assess the reasons or grounds for action and decide as reason dictates - and thus have positive freedom, that is, a will governed by (or, in Kant's case, even tantamount to) practical reason. True freedom is not a symmetrical ability to choose between good and evil, rationality and irrationality. The 'positive' case, of complying with the demands of reasons, is privileged for both Kant and Hegel.

From the viewpoint of the notion of freedom or liberty, Hegel follows Kant in two respects, but adds a third aspect: Negative freedom is the liberty to do as one pleases, and 'reflective' or 'moral' freedom consists in self-determination. Hegel however adds a third layer, 'social freedom' which is realized in institutional reality or ethical life (Sittlichkeit) which for Hegel is an actualization or realization of free will - they give objective reality to freedom analogously to how sculptures are an objectification of. ${ }^{16}$ For Hegel, action is related to reason via an ought (Sollen). Reason tells us how we ought to act (PR, §108, §131). In realized Sittlichkeit, action is related to reason via an 'is': in Sittlichkeit, we habitually act as we ought to, so it is not a mere demand, but realization (PR §141).

There remains a radical difference here. For Kant, the crucial demand on the autonomous 'Will' is that it obeys the demand of universalizability, whereas for Hegel it must obey also the more particular ethical substance or rational, objective content (found in the institutional reality). This is because he maintains that pure reason remains empty.

As is well-known, Hegel argues, contra Kant, that the universal law is empty. The charge has perhaps received more attention than it deserves, insofar as Kantians can respond that maxims have content and that only some can be conceived or willed as universal law. ${ }^{17}$ But this not the central contention between Kant and Hegel. Even if the universal law is not empty (and indeed, Hegel uses something very similar to Kant's humanity as an end-formula in his command "be a person and respect others as persons" ${ }^{18}$ ), for Hegel it simply lacks the weight that it has for Kant. This is because the former wishes to resist the latter's identification of one's true self with the self which is guided by the moral law.

On Kant's view, practical reason must be pure in order to be autonomous, it cannot be determined from the outside. For Hegel, ethical contents drawn from rational ethical life are not a threat to the autonomy of reason or Will, because the ethical institutions, if indeed rational, are themselves the products, actualizations of Reason or Will (in some suitably anonymous sense). Of course, it may well be that the existing institutional order is not rational, in which case it is not 'actual' either in Hegel's terminology, but merely 'existing', in just the same sense in which counterfeit money may exist without being actual money.

The main relevant disagreement between the two philosophers concerns the question of whether one is oneself and autonomous by putting aside all heteronomous otherness, or whether one becomes who one truly is, in and through such otherness. For Hegel, "absence of dependence on an other is won not outside the other but in it, it attains actuality not by fleeing the other but by overcoming it" (EG $\S 382 \mathrm{~A}$ ). The institutional setting (Sittlichkeit) in which I find myself may thus be something that I can identify with (as truly 'mine'). This is at least as relevant to "mineness" as the subjective capacity to think viz. the capacity of making up my mind. The same goes for other cases of being oneself in another: not only the 
institutional setting, but interpersonal influences, psychological events, and natural dispositions. The institutional reality is mostly not of my own doing, but a product of Reason and so not something alien to me.

While Kant believes that we identify with the somewhat anonymous pure practical Reason we can find 'within ourselves', Hegel maintains that we can equally identify with the somewhat anonymous Reason that we can find actualized in the institutions of our times. ${ }^{19}$ An overarching difference between Kant and Hegel, then, is that the former stresses the distinction between oneself and others whereas the latter operates within a structure, where these entities are not as easily separable, neither conceptually nor in actuality. This affects their respective approaches to an agent's relation to empirical reality ('outer' nature), to their empirical inclinations ('nature within'), to other agents, and to prevailing social reality. The relevant 'other', for Hegel, can be outer nature, the agent's own inner nature, and other agents or a system of social roles. With regard to each of these four 'others', Hegel sees the possibility of a relation in which the agent's self is realized, and through which the agent's self-relation can be mediated. One finds oneself in the results of one's actions, or works or modifications of 'outer nature'. ${ }^{20}$ The self or subject is not merely something inner, but "what the subject is, is the series of his actions" (PR 124). One's inner impulses and inclinations do not remain 'alien' to us when incorporated into one's second nature: in having formed dispositions of character in habituation and practice, they are constitutive of oneself (PR, §146-148). Similarly, recognition from others, and one's occupation of a social role in a rational society can be constitutive of oneself (cf. PR $144-145) .^{21}$

For Hegel, will is not self-determination in conformity to representation of laws, but just selfdetermination, in conformity to representation of certain ends, means, duties, and so on. Roles with certain tasks and duties are relevant in choosing the more specific ends through which the end of general happiness and freedom is served. While the differences between Kant and Hegel are important here, there remains something crucial that they share in this context, which we might put in terms of the idea in contemporary moral psychology that so-called "motivating" and "normative reasons" are, when all goes well, one and the same. $^{22}$

According to Kant, the objective principles of morality are also subjectively determining for purely rational agents such as God and the angels (who have no source of motivation which could conflict with morality and therefore automatically act as morally require). What a fully rational being realizes to be objectively necessarily is, for this being, also subjectively necessary. ${ }^{23}$ For beings like us, who do have other sources of motivation, in the ideal case, our subjective principle of action (maxim) is also an objective one, and Kant even describes the test of the Categorical Imperative as checking whether it is the latter (MM AA 6:225). While Kant speaks of principles here (called laws if objectively rational and maxims when taken as subjective), for Hegel, from the viewpoint Morality we can say that subjective and objective reasons ought to be the same, whereas in a well-ordered Sittlichkeit the subjective and objective reasons are typically the same. With regard to moral worth, Hegel allows for various other motivations and changes in external circumstances, some of them intended, some foreseen, some foreseeable, some unforeseeable, but all related to moral luck, not least that involved in 'being oneself in another'.

Of Ethical Life ('Sittlichkeit'), Hegel says the following:

The identity of the good with the subjective will, an identity which therefore is concrete and the truth of them both, is Ethical Life (PR § 141).

Ethical life is the Idea of freedom in that on the one hand it is the good become alive the good endowed in self-consciousness with knowing and willing and actualised by self- 
conscious action - while on the other hand self-consciousness has in the ethical realm its absolute foundation and the end which actuates its effort. Thus ethical life is the concept of freedom developed into the existing world and the nature of self-consciousness (PR $\S$ 142)..$^{24}$

While Kant would see such ethical contents as a source of heteronomy - or, at best, as providing the material on which our autonomy can be exercised - , for Hegel they are nothing alien - they provide the very essence of the historically situated moral agent:

On the other hand, they are not something alien to the subject. On the contrary, his spirit bears witness to them as to its own essence, the essence in which he has a feeling of his selfhood, and in which he lives as in his own element which is not distinguished from himself. The subject is thus directly linked to the ethical order by a relation which is more like an identity than even the relation of faith or trust (PR § 147).

While Hegel discusses action in the more individualistic or subjective context of Moralität (PR, §104-140), it is worth keeping in mind that he insists that individual moral action is fully understandable only in the context of such objective ethical life. Hegel's practical philosophy sublates Kant's dichotomy between juridical and ethical laws insofar as Hegel argues that both Abstract Right (PR, Part I) and Morality (PR, Part II) are fully intelligible only in the context of Ethical Life (PR, Part III). Hegel's ethics preserves many of the points that Kant makes about legality, including those about the relation of persons to deeds, the coexistence of their freedom, and the irrelevance of motives or maxims to legality.

Action ('Handlung'), for Hegel, belongs to the sphere of morality. Admittedly, in legality, there is 'actio' (PR §113R), which focuses only on the legally relevant aspects of action. Later, the institutions of Ethical Life become dependent on the members acting accordingly, but the focus there is on the institutions that actions sustain. In his analysis of action in the section on Moralität, he simply stipulates that 'the externalisation of the subjective or moral will is action ('Handlung')'. Action here implies the following determinate characteristics:

$\alpha)$ It must be known by me in its externality as mine.

$\beta$ ) its essential relation to the concept is one of obligation

ү) it has an essential relation to the will of others (PR, §113).

While there is considerable controversy over how to understand these in detail (see Laitinen \& Sandis 2010a), it is obvious that Hegel distinguishes action from other types of external events with reference to the agent's standpoint here. In referring to the "ought", he warns the reader that the analysis shares the limitation of Morality and is not yet of Sittlichkeit (where ought and is coincide), while also arguing that action is irreducibly social or interpersonal in referring to other agents, or "wills" (see Pippin 2010). ${ }^{25}$ Hegel begins by distinguishing between "deeds" brought about by the agent and other alterations in the external circumstances. Crucially, what he calls "a deed" is also an alteration in the external circumstances. ${ }^{26}$

[T] he action of the will presupposes an external object [Gegenstand] with various attendant circumstances. The deed posits an alteration to this given existence [Dasein], and the will is entirely responsible for it in so far as the abstract predicate 'mine' attaches to the existence so altered (PR, $\S 115)$. 
The category of deeds is a very broad ones, including things done accidentally, such as dropping a vase when trying to open a window. In any given "deed" there are two elements present, the "outer" element of the alteration and the "agential" or "inner" element - the agent's will is in some direct or indirect way causally connected to the alteration. What is required for causal responsibility is the causal connection between these two elements. Causal responsibility may be necessary, but is not sufficient for moral chargeability concerning deeds. It does not follow that everything I am causally responsible for may be imputed to me (see PR § 115Z):

It is, however, the right of the will to recognize as its action, and to accept responsibility for, only those aspects of its deed which it knew to be presupposed within its end, and which were present in its purpose. - I can be made accountable for a deed only if my will was responsible for it (PR § 117).

When it comes to deeds, Hegel holds that agents are accountable (morally responsible, chargeable) only for what is included in their purpose ('Vorsatz'). He illustrates this with the famous comparison to Oedipus's responsibility for parricide. Oedipus was causally responsible for the death of his father, but did not know that it was his father that he killed. He may of course be morally responsible for an intentional killing (one shouldn't go about killing non-fathers either), but it is far less obvious whether it is appropriate to hold him morally responsible for "killing one's father":

My will is responsible for a deed only insofar as I have knowledge of it [...] Oedipus, who unwittingly killed his father, cannot be accused of parricide (PR, §117Z).

For Hegel, the inner "purpose" serves to distinguish between those aspects of the "deed" that count as my "action" and those that don't (e.g. the unforeseeable contingent consequences). An action (Handlung) is an act (Tun) from the standpoint of the agent (behaviour in so far as it relates to one's own foreknowledge, purpose, intention, and knowledge) whereas the broader notion of a deed (Tat), can be seen from any other standpoint (e.g. legal, scientific, cultural, etc.). ${ }^{27}$ Whether or not we think (or think that Hegel thinks) that there are actions that are not deeds (which are alterations in the circumstances), we can say that being part of one's purpose, or being presupposed etc. is what distinguishes actions from other aspects of deeds.

Action ("Handlung") is the Purpose of the moral/subjective will (PR § 114) in the sense that it is its externalisation ( $P R \S 114$ ). Hegel characterizes action as the "translation" of the conscious purpose into the external reality - so that the content of the purpose may remain the same (in successful cases). If one's purpose is to build a house, and a house comes into existence through one's interventions, that state of affairs "contains" or embodies the same content as the original, merely mental, purpose. Hegel maintains that it is the right of the will to recognize as its action, and to accept responsibility for, only those aspects of its deed which it knew to be presupposed within its end, and which were present in its purpose. The "right of knowledge" thus states that I can be made morally accountable, chargeable, for a deed only if my will was responsible for it. (PR, $\S 117)$. Hegel thinks there has been a significant historical shift concerning this:

The heroic self-consciousness (as in ancient tragedies like that of Oedipus) has not yet progressed from its unalloyed simplicity to reflect on the distinction between deed and action, between the external event and the purpose and knowledge of the circumstances, or 
to analyse the consequences minutely, but accepts responsibility for the deed in its entirety (PR, §118R)

Yet, he also suggests that the agent will be responsible for, say, arson in its entirety or killing a whole person, even though sets fire only to one corner of the house, or hits him only on the head. Hegel adds the following crucial proviso:

There are inevitable consequences linked with every action, even if I am only bringing about some single, immediate state of affairs. The consequences in such a case represent the universal implicit within that state of affairs. Of course I cannot foresee the consequences - they might be preventable - but I must be aware of the universal character of my isolated act. The important point here is not the isolated thing but the whole, and that depends not on the differentia of the particular action, but on its universal nature. Now the transition from purpose to intention lies in the fact that I ought to be aware not simply of my single action but also of the universal which is conjoined with it. The universal which comes on the scene here in this way is what I have willed, my intention (PR 118A).

In other words, we are not only responsible for known characterizations of our actions and their effects but also for those which follow from their 'universal' character and which we ought to be aware of, even if we are not (see Houlgate 1991/2005:294)

While it is pretty clear that that is Hegel's view, there is a substantive difficulty of how to square Hegel's claims that (i) agents have the right to be held responsible only for those aspects of their deed that were in fact included in their conscious purpose or intention or foresight aka their actions, and (ii) agents are also responsible for what was not included in their conscious purpose or intention or foresight (aka their actions) but should have been foreseen in the circumstances (and would have been by a thinking agent). ${ }^{28}$ Hegel further characterizes cases of luck, which we must take responsibility for:

\begin{abstract}
It happens of course that circumstances may make an action miscarry to a greater or lesser degree. In a case of arson, for instance, the fire may not catch or alternatively it may take hold further than the incendiary intended. In spite of this, however, we must not make this a distinction between good and bad luck, since in acting a man must lay his account with externality. The old proverb is correct: 'A flung stone is the devil's'. To act is to expose oneself to bad luck. Thus bad luck has a right over me and is an embodiment of my own willing (PR 119A).
\end{abstract}

We must, then, recognise actions stemming from our will as as our own even when we haven't intended them, and accept the appropriate responsibility. ${ }^{29}$ But we must do this without making Oedipus' error of mistaking one's handlung for a tat. ${ }^{30}$ Not everything we willingly do is done intentionally or on purpose, or vice versa. ${ }^{31}$ For Kant, by contrast, what we must take responsibility for is more limited. Kant does accept that the bad results of a wrongful and the good results of a meritorious action can be imputed to us (MM AA 6: 228), but refuses to admit a general imputation the other way round.

\title{
V. Conclusion
}


This essay was an attempt to illustrate that the category of action is far more central to both Kant and Hegel's moral theories than standard interpretations suggest, and that their philosophy is all the better for it. We suggested that Kant and Hegel's differences here chiefly reside in a wider philosophical disparity between Kant's disposition to draw sharp dichotomies between things, and Hegel's desire to overcome dichotomy through "sublation". This is most salient in the general divide between "inner" and "outer" and, more specifically, self and other. Moreover, both Kant and Hegel's accounts of action are themselves subject to inner tensions that we have not attempted to resolve here. ${ }^{32}$ Kant's outlook contains a predictable tension concerning how the noumenal and phenomenal aspects of action hang together. Similarly, Hegel's various constraints on the scope of human responsibility for action are themselves in tension with one another. Nevertheless, one thing is clear: there is room for considerable exegetical developments in each case. ${ }^{33}$

\section{References}

\section{Kant}

GMM Grundlegung zur Metaphysik der Sitten. In Königlich-Preussische Akademie der Wissenschaften (ed.): Kant's Gesammelte Schriften. 29 vols. Berlin 1900-, vol. 4 (Translation in Immanuel Kant: Practical Philosophy. Translated and edited by M. Gregor. Cambridge 1996, 41-108).

CprR Kritik der praktischen Vernunft. In Königlich-Preussische Akademie der Wissenschaften (ed.): Kant's Gesammelte Schriften. 29 vols. Berlin 1900-, vol. 5. (Translation in Immanuel Kant: Practical Philosophy. Translated and edited by M. Gregor. Cambridge 1996, 193-272).

MM Metaphysik der Sitten. In Königlich-Preussische Akademie der Wissenschaften (ed.): Kant's Gesammelte Schriften. 29 vols. Berlin 1900-, vol. 6, 203-494 (Translation in Immanuel Kant: Practical Philosophy. Translated and edited by M. Gregor. Cambridge 1996, 353-604).

Religion Die Religion innerhalb der Grenzen der bloßen Vernunft. In Königlich-Preussische Akademie der Wissenschaften (ed.): Kant's Gesammelte Schriften. 29 vols. Berlin 1900-, vol. 6, 1-202 (Translation in Immanuel Kant: Religion and Rational Theology. Translated and edited by A. Wood \& G. di Giovanni. Cambridge 1996, 39-216).

Hegel

PhG Phänomenologie des Geistes (1807),in TWA, vol. 3. Hegel's Phenomenology of Spirit. Tr. A. V. Miller. Oxford: Oxford University Press, 1977.

$P R$

Grundlinien der Philosophie des Rechts oder Naturrecht und Staatswissenschaft im Grundrisse (1821); in TWA, vol. 7. Elements of the Philosophy of Right. A.W. Wood (ed.). Tr. H. B. Nisbet. Cambridge: Cambridge University Press, 1991. Cited by section (§) number.

TWA Werke. Theorie-Werkausgabe. 20 volumes and register. E. Moldenhauer \& K. M. Michel (eds). Frankfurt a. M.: Suhrkamp, 1969-79. 


\section{Secondary literature}

Alznauer, M. (2015), Hegel's Theory of Responsibility (Cambridge: Cambridge University Press).

Anscombe, G.E.M. (1957), Intention (Oxford: Blackwell).

(1979), 'Under a Description', in Noûs, vol. 13, 219-233.

Dancy, J. (2000), Practical Reality (Oxford: Oxford University Press).

Davidson, D. (1980/2001), Essays on Actions and Events, 2nd revised edition (Oxford: Clarendon Press).

Houlgate, S. (1991/2005), Hegel: Freedom, Truth and History, $2^{\text {nd }}$ edition (Oxford: Blackwell).

(2010),'Action, Right and Morality in Hegel's Philosophy of Right', in Laitinen \& Sandis

(2010a:155-175).

Deligiorgi, K. (2006) (ed.), Hegel: New Directions (Chesham: Acumen).

Engstrom, S. (2009), The Form of Practical Knowledge: A Study of the Categorical Imperative (Boston, MA: Harvard University Press).

Houlgate, S. (1991/2005), Hegel: Freedom, Truth and History, 2nd edition (Oxford: Blackwell).

Inwood, M. (1982), 'Hegel on Action,' Royal Institute of Philosophy Lectures, 13, 141-154.

Knowles, D. (2002), Hegel and the Philosophy of Right (London: Routledge).

Korsgaard, C. (2009), Self-Constitution. Agency, Identity, and Integrity (Oxford: Oxford University Press).

Laitinen, A. \& Sandis, C. (2010a) (eds.) Hegel on Action (Basingstoke: Palgrave Macmillan).

(2010b), 'Hegel and Contemporary Philosophy of Action'; in Laitinen \& Sandis (2010a: 1-21).

(2019), 'Hegel on Purpose', Hegel Bulletin - special issue on Hegel and the Philosophy of Action

(eds. E. Maraguat \& C. Sandis).

McCarthy, R. (2009), Kant's Theory of Action (Oxford: Oxford University Press).

Moyar, D. (2010), Hegel's Conscience (Oxford: Oxford University Press).

Neuhouser, F. (2000), Foundations of Hegel's Social Theory: Actualizing Freedom. (Cambridge, MA: Harvard University Press).

O'Neill, O. (1975), Acting on Principle: An Essay in Kantian Ethics (New York, NY: Columbia University Press). Pettit, Philip and Smith, Michael (1990) Backgrounding Desire. The Philosophical Review, 99: 4, 565-592

Pinkard, T. (1994). Hegel's Phenomenology: The Sociality of Reason (Cambridge: Cambridge University Press).

Pinkard, T. (2010), 'Freedom and the Lifeworld', in Laitinen \& Sandis (2010a:137-154).

Pippin, R. B. (2008), Hegel's Practical Philosophy: Rational Agency as Ethical Life Cambridge: Cambridge University Press).

(2010),'Hegel's Social Theory of Agency: the 'Inner-Outer' problem; in Laitinen \& Sandis (2010a:59-78).

Quante, M. (2004), Hegel's Concept of Action, trns. D. Moyer (Cambridge: Cambridge University Press). (2010) in Laitinen \& Sandis (2010a:59-78)

Ross, W.D. (1930/2002), The Right and the Good, revised edition edited by P. Stratton-Lake (Oxford: Clarendon Press).

Rousseau, J-J (1762/1988), On The Social Contract. (Hackett)

Sandis, C. (2010)' The Man who Mistook his Handlung for Tat: Hegel on Oedipus and Other Tragic Thebans', Hegel Bulletin, Vol. 31, Iss. 2 (Oct), 35-60. 
(2015), 'Motivated by the Gods: Compartmentalized Agency \& Responsibility', in (eds.) A. Buckareff, C. Moya, \& S.Rosell, Agency and Responsibility (Basingstoke: Palgrave Macmillan), 209225.

Siep, L. (1983), 'The 'Aufhebung' of Morality in Ethical Life' in Stepelevitch \& Lamb (1983: 137-155). Stepelevitch, L.S. \& Lamb, D. (1983), (eds.) Hegel's Philosophy of Action (Atlantic Highlands, N.J.: Humanities Press).

Taylor, C. (1983), 'Hegel and the Philosophy of Action', as reprinted in Laitinen \& Sandis (2010a:22-41). Westphal, K. (1991), 'Hegel's Critique of Kant's Moral World View', Philosophical Topics, 19:2, 133-175. Wood, A. (1990), Hegel's Ethical Thought (Cambridge: Cambridge University Press). (2010),'Hegel on Responsibility for Actions and Consequences', in Laitinen \& Sandis (2010a:119136).

Yeomans, C. (2012), Freedom and Reflection: Hegel on the Logic of Agency (Oxford: Oxford University Press).

1 For treatments of Kant's philosophy of action see Engstrom (2009), McCarthy (2009), Korsgaard (2009). For treatments on Hegel's philosophy of action, see Alznauer (2015), Houlgate (2010), Inwood (1982), Knowles (2002), Laitinen \& Sandis (2010a), Stepelevich \& Lamb (1983), Moyar. (2010), Pinkard (2010), Pippin (2008), Quante (2004), Siep (1983), Taylor (1983), Wood (1990), and Yeomans (2012).

2 GMM AA 4: 394.

3 Kant does not consider moral duties to be essentially directed towards other persons or to be 'relational'. For Kant, there are not only duties to others, but also duties to oneself. None of this is to deny that moral community in the form of the 'kingdom of ends' does play an important part in Kant's moral thought (esp. GMM AA 4: 438). But even here, the key idea is only that every rational agent must act as if he were a member of this community, and, again, strictly speaking, no actual relations to other agents are needed.

4 For a short overview of Kant's relation to this tradition, see Engstrom (2009:25).

5 MS AA 6: 211.

6 MS AA 6: 211.

7 MS AA 6: 213. Kant's terminology on this point has undergone some changes throughout his work, though. In the Groundwork, for instance, he uses 'inclination' (Neigung) simpliciter of the motives to action which spring from our sensibility to contrast them with the motives which are produced by reason (i.e. the motive of reverence, see below), see, e.g. AA 4: 454.

8 Cf. Engstrom (2009: 27).

${ }^{9}$ For this identification see also Engstrom (2009:30).

10 Korsgaard (2009:78).

11 For discussion, see Neuhouser 2000, ch 2

12 Kant presents this argument (for 'free will') at the beginning of Section III of the Groundwork, AA 4: 446f.

${ }^{13}$ The same point (i.e. that all laws are addressed to the faculty of choice) becomes clear in Kant's definition of 'deed', which is, again, meant to be neutral on whether the laws in question are juridical or ethical.

"An action is called a deed insofar as it comes under obligatory laws and hence insofar as the subject, in doing it, is considered in terms of the freedom of choice. By such an action the agent is regarded as the author of its effect, and this, together with the action itself, can be imputed to him, if one is previously acquainted with the law by virtue of which the obligation rests on these" (MM 6: 223).

${ }^{14}$ See, for instance, Kant's famous discussion of the four examples for perfect and imperfect duties in GMM 4: 422 ff., which clearly suggest this picture, since Kant is asking us to imagine everyday processes of deliberation.

15 Cf. Yeomans (2012).

16 See Neuhouser (2000).

17 See O'Neill (1975).

18 PR §36.

${ }^{19}$ This is not to say that all institutions are products of Reason. Some definitely are no more so than any old whims are subjective products of Reason. 
${ }^{20} \mathrm{Hegel}$ understands action or "activity of the will" as "sublating" the distinction between subjectivity and objectivity and as "translating" the subjective ends in the objective reality "while at the same time remaining with itself in this objectivity" (PR, §28).

${ }^{21}$ For Hegel, recognition from others is necessary for the existence of self-consciousness. "Self-consciousness exists in and for itself when, and by the fact that, it so exists for another; that is, it exists only as something acknowledged".(Phenomenology of Spirit, trans. Miller 1977, §178)

${ }^{22}$ For the now classic defence of this idea see Dancy (2000).

23 GMM AA 4: 412.

${ }^{24}$ Hegel further compares the way that individuals relate to ethical life to how accidents relate to substances: "[T]he ethical order is freedom or the absolute will as what is objective, a circle of necessity whose moments are the ethical powers which regulate the life of individuals. To these powers individuals are related as accidents to substance, and it is in individuals that these powers are represented, have the shape of appearance, and become actualized" (PR § 145). Formulations such as are a worry for individualists.

${ }^{25}$ On one understanding the reference to others' wills is a matter of actions containing implicit "validity claims" for others' approval: that in acting, I make the implicit claim that so acting is right (Alznauer 2015).

${ }^{26}$ Note that this choice of a starting point is not innocent. Hegel's definition of deed as "alteration" may lead to difficulties when discussing responsibility for omissions, failures to act, or especially actions which successfully prevent alterations in the circumstances (say, keeping the door closed so that the wind doesn't open it).

${ }^{27}$ This distinction should not be confused with the contemporary one between action and mere bodily movement. For one, both Handlung and Tat are aspects of conduct that results from the will, viz. Tun. Moreover, Hegel's taxonomy is motivated purely by concerns relating to modes of perception. So, whereas theorists such as Donald Davidson assert that all actions are events that are intentional under some description, Hegel reserves the term 'action' for those aspects of behaviour that are highlighted by a specific (albeit contested) set of agent-related descriptions. This is not an ontological category, since there are no such objects as actions-under-specific-descriptions (cf. Anscombe 1979; Laitinen \& Sandis 2010b; Sandis 2010).

${ }^{28}$ This question is addressed in Laitinen \& Sandis (2019).

29 See Sandis (2015).

30 See Sandis (2010).

31 For interpretational disputes that we cannot get into here, see Laitinen \& Sandis (2010b \& 2019).

${ }^{32}$ But see Laitinen \& Sandis (2019) for an attempt to dissolve the tension in Hegel.

${ }^{33}$ Earlier versions of this paper were presented at the fortnightly philosophy of action TORCH seminar at The Queen's College, Oxford (2012), and the Philosophical Accounts of Action 1500-2000 conference at the Institute of Philosophy, Senate House London, 16-17 May 2013. We thank both audiences for their helpful comments and questions, as well as two anonymous referees and Louise Chapman. 